\title{
Stromal cells from the adipose tissue-derived stromal vascular fraction and culture expanded adipose tissue-derived stromal/stem cells: a joint statement of the International Federation for Adipose Therapeutics and Science (IFATS) and the International Society for Cellular Therapy (ISCT)
}

\author{
PHILIPPE BOURIN ${ }^{1}$, BRUCE A. BUNNELL ${ }^{2}$, LOUIS CASTEILLA ${ }^{3}$, \\ MASSIMO DOMINICI ${ }^{4}$, ADAM J. KATZ ${ }^{5}$, KEITH L. MARCH ${ }^{6}$, HEINZ REDL $^{7}$, \\ J. PETER RUBIN ${ }^{8}$, KOTARO YOSHIMURA ${ }^{9} \&$ JEFFREY M. GIMBLE $^{10}$
}

${ }^{1}$ CSA21, Toulouse, France, ${ }^{2}$ Center for Stem Cell Research and Regenerative Medicine, Department of Pharmacology, Tulane University School of Medicine, New Orleans, Louisiana, USA, ${ }^{3}$ StromaLab, UMR UPS/CNRS/EFS 5273, Inserm U1031, Toulouse, France, ${ }^{4}$ Laboratory of Cell Biology and Advanced Cancer Therapies, Department of Medical and Surgical Sciences for Adults and Children, University Hospital of Modena and Reggio Emilia, Modena, Italy, ${ }^{5}$ Division of Plastic and Reconstructive Surgery, Department of Surgery, University of Florida, Gainesville, Florida, USA, ${ }^{6}$ Indiana Center for Vascular Biology and Medicine, Indiana University School of Medicine, Indianapolis, Indiana, USA, ${ }^{7}$ Ludwig Boltzmann Institute for Experimental and Clinical Traumatology in AUVA Research Center, Austrian Cluster for Tissue Regeneration, Vienna, Austria, ${ }^{8}$ Department of Plastic Surgery, University of Pittsburgh, Pittsburgh, Pennsylvania, USA, ${ }^{9}$ Department of Plastic Surgery, University of Tokyo School of Medicine, Tokyo, fapan, and ${ }^{10}$ Stem Cell Biology Laboratory, Pennington Biomedical Research Center, Louisiana State University System, Baton Rouge, Louisiana, USA

\begin{abstract}
Background aims. Adipose tissue is a rich and very convenient source of cells for regenerative medicine therapeutic approaches. However, a characterization of the population of adipose-derived stromal and stem cells (ASCs) with the greatest therapeutic potential remains unclear. Under the authority of International Federation of Adipose Therapeutics and International Society for Cellular Therapy, this paper sets out to establish minimal definitions of stromal cells both as uncultured stromal vascular fraction (SVF) and as an adherent stromal/stem cells population. Methods. Phenotypic and functional criteria for the identification of adipose-derived cells were drawn from the literature. Results. In the SVF, cells are identified phenotypically by the following markers: CD45-CD235a-CD31-CD34+. Added value may be provided by both a viability marker and the following surface antigens: CD13, CD73, CD90 and CD105. The fibroblastoid colony-forming unit assay permits the evaluation of progenitor frequency in the SVF population. In culture, ASCs retain markers in common with other mesenchymal stromal/stem cells (MSCs), including CD90, CD73, CD105, and CD44 and remain negative for CD45 and CD31. They can be distinguished from bone-marrow-derived MSCs by their positivity for CD36 and negativity for CD106. The CFU-F assay is recommended to calculate population doublings capacity of ASCs. The adipocytic, chondroblastic and osteoblastic differentiation assays serve to complete the cell identification and potency assessment in conjunction with a quantitative evaluation of the differentiation either biochemically or by reverse transcription polymerase chain reaction. Conclusions. The goal of this paper is to provide initial guidance for the scientific community working with adipose-derived cells and to facilitate development of international standards based on reproducible parameters.
\end{abstract}

Key Words: adipose-derived stromal/stem cells, adipose tissue, characterization, function, phenotype, stromal vascular fraction

\section{Introduction}

The use of adipose tissue-derived progenitors as a therapeutic has grown substantially in the past decade and has sparked the growth of a new research field and industry worldwide. Nevertheless, there still remain some unclear aspects in the literature and in the medical 
community about the identity of adipose tissue-derived cell populations. This field is at a juncture similar to that faced a few years ago by the field of bone marrow mesenchymal stromal/stem cells (MSCs). Under the authority of the International Society for Cellular Therapy (ISCT), researchers in the MSC field issued a bold statement defining the identity of the MSC (1). Our intent in this paper is to build such a statement under the joint authorities of the International Federation of Adipose Therapeutics and Sciences (IFATS) and the ISCT describing both stromal cells from the stromal vascular fraction (SVF) of the adipose tissue and the adipose tissue-derived stromal cells. Recognizing that this is a dynamic field that will require further standardization, our goal is to establish a "living" document that will be modified in response to new data and findings from ongoing and future pre-clinical and clinical studies. This document does not intend to establish policies that may restrict future advances; rather, it is designed to provide guidance that promotes further biologic clarifications, best clinical practices and safety to improve efficacious adipose tissue-derived cell therapies that benefit society.

\section{Definitions}

The following definitions are pertinent to our discussion. Stromal cells are connective tissue cells of any organ. A progenitor is cell that has a limited proliferation potential and is able to differentiate into one or several specific cell types. A stem cell is here characterized by its ability to self-renew and its multipotency.

\section{Status of adipose tissue for cell engineering and regenerative medicine}

The medical community and general public perception of adipose tissue as an organ has changed dramatically over the past 4 decades. Within this period, the incidence of obesity has increased substantially, reaching levels of $\geq 30 \%$ of the population of many economically advantaged nations. Although obesity is less common in economically developing countries, numbers of overweight and obese citizens in these countries also have increased. Increased obesity has led to changes in medical practices, one of which is far greater numbers of elective surgical abdominoplasties and lipoaspirates. Although adipose tissue has been routinely discarded as a medical waste, plastic surgeons and other investigators have documented the use of adipose tissue as an abundant and accessible source of multipotent stromal cells for regenerative medicine (2). Since initial reports in the late 1960s (3), multiple independent laboratories have established that stromal cells similar to those identified in bone marrow (4) can be isolated in a reproducible manner from adipose tissue that is either resected as intact tissue or aspirated using tumescent liposuction $(5,6)$. Although a common procedure is lacking, in general minced adipose tissue is digested by one or more of the following: collagenase, dispase, trypsin or related enzymes. A consensus exists regarding temperature $\left(37^{\circ} \mathrm{C}\right.$ ), digestion duration times (range, $30 \mathrm{~min}$ to $>1$ h) and ratios of tissue weight to volume; however, protease concentrations are far more variable.

Following the neutralization of the enzymes, the released elements, defined as the SVF, are separated from the mature adipocytes by differential centrifugation, which can substantially differ according to the protocols. The SVF consists of a heterogeneous mesenchymal population of cells that includes not only adipose stromal and hematopoietic stem and progenitor cells but also endothelial cells, erythrocytes, fibroblasts, lymphocytes, monocyte/macrophages and pericytes, among others $(7-11)$. When SVF cells are seeded into culture, a subset of elongated cells begins to adhere to the tissue culture plasticware. These cells can be purified further using a combination of washing steps and culture expansion with media similar to the ones used for bone marrow MSCs to deplete most of the hematopoietic cell population from the SVF cells. This process allows the emergence of an adherent cell population termed adipose tissue-derived stromal cells (ASCs). Although ASCs are less heterogeneous than SVF cells, they are by no means homogeneous. ASCs include multipotent cells with the ability to differentiate into adipocytes, chondrocytes, and osteoblasts, among other lineage pathways $(2,12-16)$. In this respect, the ASCs exhibit properties similar to bone marrow MSCs, leading some investigators to suggest that the two populations are identical; however, numerous features distinguish these two cell populations. For example, ASCs seem more prone to differentiate into muscle cells or even into cardiomyocytes compared with bone marrow MSCs (17), while being less robust in chondrogenic and osteogenic properties according to some reports $(18,19)$. Variability between the ASCs and bone marrow MSCs may reflect, in part, the different microenvironment or "niches" where these cells reside in their respective tissues of origin and the differences in ex vivo expansion protocols.

Clinical research on these adult stromal cell populations has accelerated, and multiple clinical investigations are underway to examine the use of ASCs, SVF cells, and bone marrow MSCs for tissue engineering and regenerative medical applications (20-22). Methods to isolate SVF cells using mechanical, non-enzymatic techniques are being developed, and some have been applied in clinical practice. For these reasons, it is time to develop a 
concise statement defining the unique characteristics and properties of human stromal cells from SVF cells and ASCs. We have restricted our description of the heterogeneous SVF cell populations to stromal cells alone because ASCs are derived from this SVF subpopulation. Such information will begin to establish a common definition and terminology that will facilitate communication across the academic, biotechnology, medical and regulatory communities, ensuring that patients will benefit from safe and efficacious adipose tissue-derived cell products in the near future. In the following sections, we present recommended parameters for a basic characterization of both SVF cells and ASCs.

\section{Phenotyping SVF}

Compared with the bone marrow mononucleated fraction generating MSCs, the SVF contains a higher percentage of stromal elements (Table I), although multiple other lineages, most notably those of endothelial, hematopoietic and pericytic origin, are also present $(11-13,23)$. Endothelial, hematopoietic and pericytic lineages represent $10-20 \%, 25-45 \%$ and $3-5 \%$, respectively, of the total nucleated cells (Table II). The degree of heterogeneity depends, in part, on the adipose tissue depot site and the digestion protocol; there are no sufficient data on the impact of these different enzymatic and mechanical procedures in antigen expression. Because there is no single marker to identify SVF cell sub-populations and the ones used are not exclusive of a mononucleated subpopulation, we suggest using multi-color identification with a combination of fluorochrome-labeled antibodies to surface antigens and one viability marker. The latter is recommended to eliminate dead or apoptotic cells induced by the isolation protocol, which could distort the analysis. Viability is recommended to be $>70 \%$ to allow for good cell expansion. Careful attention should be given in obtaining single cell suspensions before the analyses to avoid cell

Table I. Differences between bone marrow and adipose tissue.

\begin{tabular}{lcccc}
\hline & SVF & BM-NC & ASC & MSC \\
\hline CD34 & + & \pm & \pm & - \\
CD45 & + & ++ & - & - \\
CD13 & \pm & ++ & ++ & ++ \\
CD73 & \pm & \pm & ++ & ++ \\
CD90 & \pm & \pm & ++ & ++ \\
CD105 & \pm & \pm & ++ & ++ \\
CD10 & & & ++ & \pm \\
CD36 & & & + & - \\
CD106 & & & \pm & + \\
CFU-F & $>1 \%$ & $>0.001 \%$ & $>5 \%$ & $>5 \%$ \\
\hline
\end{tabular}

$++=>70 \%,+=>30-70 \%, \pm=>2-30 \%,-=<2 \%$.

$\mathrm{BM}-\mathrm{NC}$, bone marrow nucleated cells.
Table II. Cell populations resident in SVF.

\begin{tabular}{lc}
\hline Hematopoietic-lineage cells & \\
Stem and progenitor cells & $<0.1 \%$ \\
Granulocytes & $10-15 \%$ \\
Monocytes & $5-15 \%$ \\
Lymphocytes & $10-15 \%$ \\
Endothelial cells & $10-20 \%$ \\
Pericytes & $3-5 \%$ \\
Stromal cells & $15-30 \%$ \\
\hline
\end{tabular}

doublets and overlapping phenotypes in fluorescenceactivated cell sorter assessment as a result of cell clustering. The analysis additionally should rely on well-standardized gating parameters as critical aspects, given the presence of debris from the digestion and possible non-specific binding (Figure 1).

For the stromal component of the SVF, based on existing literature, we propose a combination of negative and positive markers. CD45 (leukocyte common antigen) is the classic marker to identify cells of hematopoietic origin except for red blood cells and should be excluded. As an alternative to erythrocyte lysis (a standard method to remove erythrocytes), we propose the inclusion of CD235a (glycophorin A) to monitor directly any contaminating erythroid lineage cells. Despite the fact that many SVF isolation protocols include a means to eliminate red blood cells (i.e., ammonium chloride or density gradients), it remains to be determined whether this process could disturb the final analysis. CD31 (PECAM-1) is a classic marker for endothelial cells and their progenitors, although it is also detected on platelets and leukocytes. In combination with CD45, CD31 allows the exclusion of $\mathrm{CD} 45^{-} \mathrm{CD} 31^{+}$endothelial populations. CD 34 expression is shared by hematopoietic stem/progenitor cells and endothelial cells $(8,24-26)$. However, according to published data from our groups and others, it is also a potential marker that should be used to identify the stromal cell-containing population $(8,24-26)$. There are multiple classes of CD34 antibodies recognizing unique immunogens. Consequently, the choice of CD34 antibody can substantially influence the signal intensity detected on a given cell population. Based on the current literature (27), we recommend the use of class III CD34 antibodies for SVF cell characterization (i.e., clone 581 or $4 \mathrm{H} 11$ ). Within the SVF, some studies have characterized a stromal cell population, excluding hematopoietic and endothelial cells, based on the following combination: $\mathrm{CD} 45^{-} \mathrm{CD} 235 \mathrm{a}^{-} \mathrm{CD} 31^{-} \mathrm{CD} 34^{+}$. According to different publications, this population represents at least $20 \%$ of the cells of the SVF (15). The percentage of $\mathrm{CD} 34^{+}$cells depends on the method of adipose tissue harvest, the degree of vascular hemorrhage and the subsequent digestion and isolation techniques. Four additional markers have been used to identify 
A
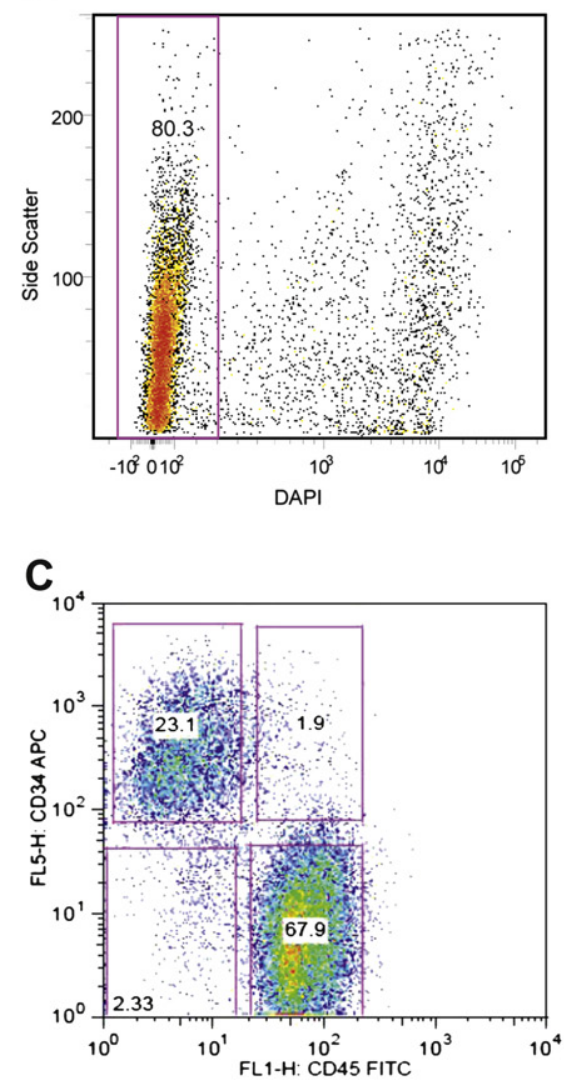

E

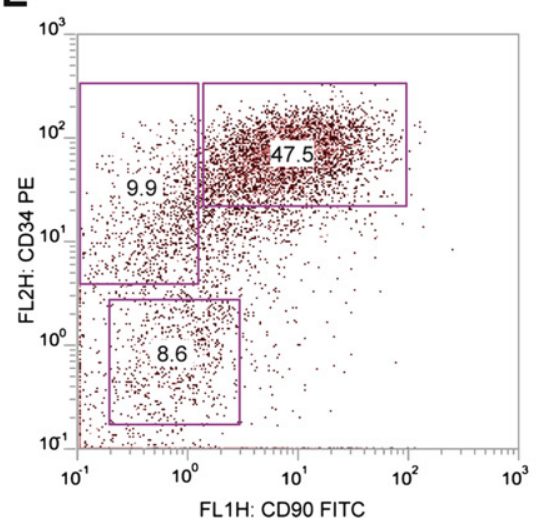

B

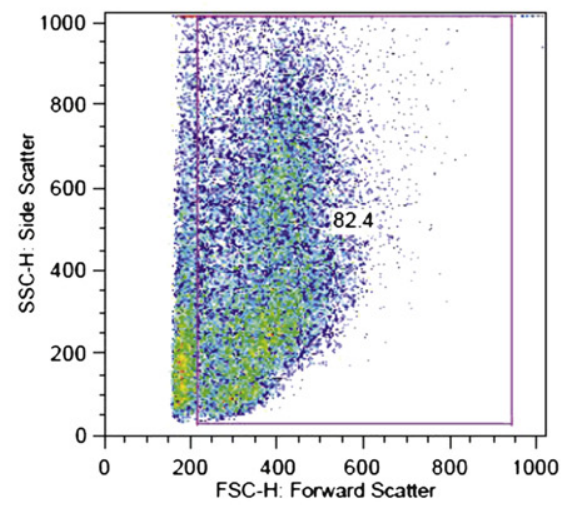

D

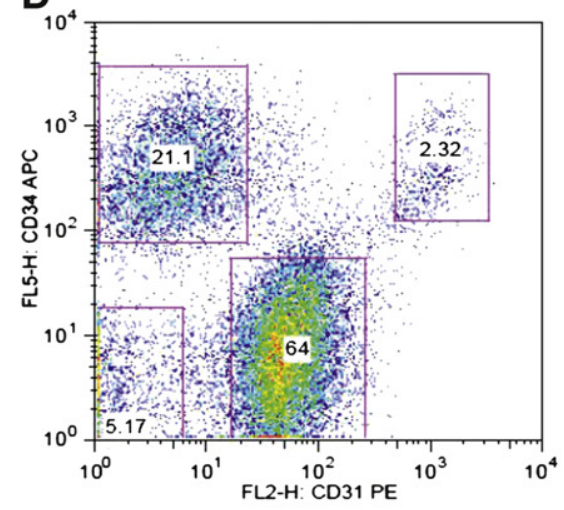

F

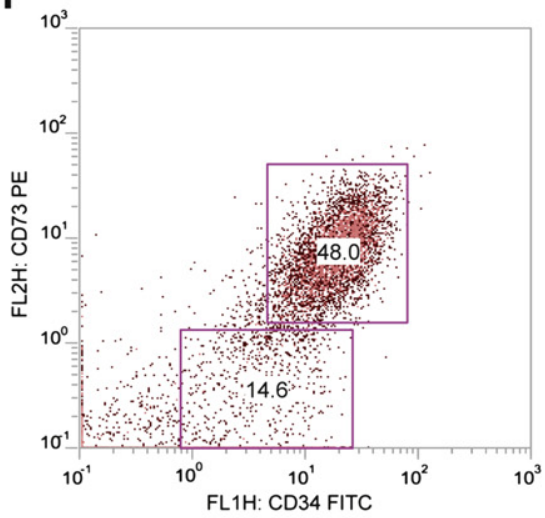

Figure 1. Illustration of a strategy for the analysis of the cells of the SVF by flow cytometry. The cell suspension undergoes a red blood cell lysis before antibody labeling, and dead cells are excluded by DAPI labeling. (A) Analysis of live (Dapi ${ }^{-}$) and dead (Dapi ${ }^{+}$) cells. (B) Forward and side scatterplot gated on live cells to identify the cell populations; the gate excludes the cell debris. (C) The markers CD34 and CD45 distinguish two different $\mathrm{CD} 34^{+}$cell populations according to CD45. Stromal cells are CD34 ${ }^{\text {bright }} \mathrm{CD} 45^{-}$. (D) The marker combination CD34 and $\mathrm{CD} 31$ distinguishes stromal cells $\mathrm{CD} 34^{\text {bright }} \mathrm{CD} 31^{-}$from the endothelial cells CD $34^{+} \mathrm{CD} 31^{+}$. (E, F) An example of analysis of CD $45^{-}$cell populations using CD34 and CD73 or CD90 markers. Most of the CD45 ${ }^{-}$CD $34^{\text {bright }}$ cells are $\mathrm{CD} 73^{+}$or $\mathrm{CD}^{+} 0^{+}$. The antibodies were purchased from Becton-Dickinson (San Jose, CA, USA), Beckman-Coulter (Miami, FL, USA), eBioscience (San Diego, CA, USA) and Biolegend (San Diego, CA, USA). The plots came from several laboratories of the authors.

SVF: CD13 (APN), CD73 (L-VAP-2), CD90 (Thy-1) and CD105 (Endoglin). Because CD90 and CD105 are also expressed by the endothelial population, they may not be optimal selections as sole markers but are best used in combination with others. Both CD13 and CD73 markers are highly expressed on the $\mathrm{CD} 45^{-} \mathrm{CD} 31^{-} \mathrm{CD} 34^{+}$cell population and may help to identify stromal cells better. $\mathrm{CD} 13^{+}$and $\mathrm{CD}_{73^{+}}$cells have been described to represent around $80 \%$ and $70 \%$ of the $\mathrm{CD} 45^{-} \mathrm{CD} 31^{-} \mathrm{CD} 34^{+}$cell population, respectively (26). Alternative positive stromal cell markers, including CD10 (CALLA), CD29 
$\left(\beta_{1}\right.$ integrin), and CD49 (VLA) isoforms, have been identified, and these can also be considered for characterization purposes.

\section{Fibroblastoid colony-forming unit evaluation}

The fibroblastoid colony-forming unit (CFU-F) assay is the standard to define the number of progenitor cells. This assay, modified from the one performed for bone marrow MSCs (28), takes 11-14 days of culture (29). The cell suspension of SVF should be seeded at low density (40-400 cells $/ \mathrm{cm}^{2}$ ) to allow each clone to grow separately in a medium carefully chosen to allow clone growth (29). After fixation and staining, clones with $>50$ cells are enumerated. In general, the frequency of stromal progenitors ranges from $1 \%-10 \%$ relative to the total nucleated cell population. It is recommended that the CFU-F assay be performed at least with two or more cell concentrations in triplicate for each donor to minimize assay variations. The number of colonies allows for an estimation of the rate of doubling of the population during the primary phase of culture. The information gained from CFU-F would be particularly useful to enhance the quality control of any resulting cell therapy product.

\section{Identification of ASCs after culture}

We propose the following main features and optional properties.

\section{Phenotyping ASCs}

As described earlier, ASCs are selected by adhesion from SVF cells and are related to MSCs, just as SVF cells can be compared with the bone marrow mononuclear cell fraction (Tables I,III). One main difference between SVF cell and ASC suspensions is the high level of CD45 $5^{+}$cells in the SVF cells and the low or undetectable level in ASCs. We propose to adapt the characterization strategy for MSCs as presented in the ISCT statement paper with some modifications as guidelines for the better characterization of these adipose precursors (1). As employed for the phenotyping of the SVF cells, we suggest the use of multi-color analysis. Flow cytometry can be used to define and validate the

Table III. Guidelines for characterization of adipose tissue-derived cells.

\begin{tabular}{|c|c|c|c|}
\hline Feature & Assay & Cells of SVF & ASCs \\
\hline Viability & $\begin{array}{l}\text { Vital stain } \\
\text { by flow cytometry } \\
\text { or microscopy }\end{array}$ & $>70 \%$ viable & $>90 \%$ viable \\
\hline Immunophenotype & Flow cytometry & $\begin{array}{l}\text { Primary stable positive } \\
\text { markers for stromal cells: } \\
\text { CD13, CD29, CD44, CD73, } \\
\text { CD90 (>40\%), CD34 }(>20 \%) \\
\text { Primary negative markers for } \\
\text { stromal cells:CD31 }(<20 \%) \text {, } \\
\text { CD45 }(<50 \%)\end{array}$ & $\begin{array}{l}\text { Primary stable positive markers: CD13, } \\
\text { CD29, CD44, CD73, CD90, CD105 } \\
\text { (>80\% in ASC) } \\
\text { Primary unstable positive marker: CD } 34 \\
\text { (present at variable levels) } \\
\text { Primary negative marker: CD 31, CD } 45 \text {, } \\
\text { CD235a (<2\%) } \\
\text { Secondary other positive markers: CD10, } \\
\text { CD26, CD36, CD49d, CD49e } \\
\text { Secondary other low or negative markers: } \\
\text { CD3, CD11b, CD49f, CD106, } \\
\text { PODXL }\end{array}$ \\
\hline $\begin{array}{l}\text { Proliferation and } \\
\text { frequency }\end{array}$ & CFU-F & Anticipated frequency: $>1 \%$ & Anticipated frequency: $>5 \%$ \\
\hline $\begin{array}{l}\text { Adipogenic } \\
\text { differentiation }\end{array}$ & $\begin{array}{l}\text { Histochemistry, } \\
\text { RT-PCR, Western } \\
\text { blot immunoblot, } \\
\text { ELISA }\end{array}$ & & $\begin{array}{l}\text { Histology: oil red } \mathrm{O} \text {, Nile red or stain } \\
\text { specific for lipid inclusions } \\
\text { Biomarkers: adiponectin, C/EBP } \alpha \text {, } \\
\text { FABP4, leptin, PPAR } \gamma\end{array}$ \\
\hline $\begin{array}{l}\text { Chondrogenic } \\
\text { differentiation }\end{array}$ & & & $\begin{array}{l}\text { Histology: alcian blue or safranin O } \\
\text { Biomarkers: aggrecan, collagen type II, } \\
\text { Sox } 9\end{array}$ \\
\hline $\begin{array}{l}\text { Osteogenic } \\
\text { differentiation }\end{array}$ & & & $\begin{array}{l}\text { Histology: alizarin red or von Kossa } \\
\text { Biomarkers: alkaline phosphatase, bone } \\
\text { sialoprotein, osteocalcin, osterix, runx } 2\end{array}$ \\
\hline
\end{tabular}

The information in this table represents recommended guidelines only and is not to be construed as industry standards or regulatory definitions at this time. The level of positivity for surface antigens may vary between ASCs and SVF cells because differences in intensity have been noted for the markers CD34, CD49d and CD146.

$\mathrm{C} / \mathrm{EBP} \alpha$, CCAAT enhancer binding protein $\alpha$; ELISA, enzyme-linked immunosorbent assay; FABP4, fatty acid binding protein 4; PPAR $\gamma$, peroxisome proliferator activated receptor $\gamma$; RT-PCR, reverse transcription polymerase chain reaction. 
relative homogeneity or, alternatively, the heterogeneity (i.e., potential contamination) of the ASCs. A viability dye should be included, particularly if a viability dye such as trypan blue is not included when counting or if the frequency of dead cells is $>30 \%$. The immunophenotype should be comparable to the immunophenotype used to define the SVF cells, identifying a population enriched for $\mathrm{CD} 45^{-} \mathrm{CD} 31^{-}$. We recommend that the analysis include surface antigens used to characterize the MSCs: CD73, and CD90 (Table III). In addition, we suggest including CD13 as an alternative or supplement to CD105 for two reasons: (i) the commercial antibodies targeting this antigen exhibit higher specificity and signal intensity, and (ii) the expression level is often higher and more stable. However, it remains possible that there will be added value in distinguishing between the properties of $\mathrm{CD}_{105^{-}}$and $\mathrm{CD} 105^{+}$ASC subpopulations.

ASCs should be negative $(<2 \%)$ for hematopoietic markers such as CD11b and CD45 and positive (>90\%) for stromal markers such as CD13, CD73 and CD90 (Tables I,III). In addition, to distinguish ASCs from marrow MSCs, we propose using two other markers, CD36 (GPIIIb) and CD106 (VCAM-1), because it has been published that ASCs, in contrast to MSCs, do not express CD106 but are positive for CD36 (24,26,30). As an example of comparison, we provide a phenotypic analysis of MSCs and ASCs in Figure 2. The expression of CD34 greatly depends on the culture condition. It is generally expressed during the early phase of culture (within $8-12$ population doublings after culture of the SVF), but then its expression decreases with continued cell division as reported earlier $(9,26)$. We propose that a foundational phenotyping should include at least two negative markers and two positive markers in the same analysis. Additional markers will strengthen the characterization. We suggest CD10, CD26 (DPPIV), CD49d (VLA4), CD49e (VLA5) and CD146 (MUC18) as additional positive markers but with variable expression depending on the donor or culture passage and CD3, CD11b (Mac-1), CD49f (VLA6) and Podocalyxin like protein (PODXL) as markers with negligible expression $(<2 \%)$ levels (Table III). Even when defined by these basic surface antigens, we anticipate that ASC populations may further display heterogeneity for additional surface antigens (24).

\section{Functionality of ASCs}

A hallmark of the ASCs is their multipotency and ability give rise to osteoblastic, chondrocytic and adipocytic lineages $(2,5,12)$. Differentiation protocols have been extensively published, and some manufacturers offer "off-the-shelf" lineage-specific inductive media. Although a qualitative assessment of the differentiation based on histochemistry is helpful, it may not be sufficient for rigorous analysis. For instance, many cells can store lipids with no expression of adipocyte differentiation program (i.e., hepatocytes, muscle cells). A quantitative approach may be beneficial for the characterization and documentation of ASC differentiation potential. A selection of lineage-specific gene or protein biomarkers can be made from the following based on published data: for adipogenesis (adiponectin, fatty acid binding protein 4, leptin, peroxisome proliferator activated receptor $\gamma$, glycerol 3 phosphate dehydrogenase); for chondrogenesis, aggrecan, collagen type II, Sox9; for osteogenesis, alkaline phosphatase, bone sialoprotein, osteocalcin, osterix, runx2 $(2,12,13,31,32)$. Within dedicated readouts for specific intent, one may assess the cell function by up-regulation of biomarkers. To adopt a coherent approach with the characterization of the SVF, we also suggest performing an evaluation of progenitor frequency by a secondary CFU-F assay where passage 1 ASCs are seeded at a density of $2-4$ cells $/ \mathrm{cm}^{2}$ and evaluated for colony formation after an 11-14 day incubation period.

\section{Conclusions}

The goal of this paper is to provide initial guidance to academia, industry and regulatory authorities regarding the minimal properties expected for adipose tissue-derived cells (summarized in Table III). The features described in this paper are designed to facilitate further progressive development of international standards based on reproducible parameters and endpoints that will possibly harmonize cellular products across boundaries and accelerate the delivery of safe and effective ASC-based tools to the medical community and the patients it serves. This characterization may be completed in relation to specific uses of ASCs or SVF cells. For example, it may be important to test the secretion of a defined factor or to evaluate a specific set of genes, microRNAs or proteins expressed by ASCs as a quantifiable potency test. By establishing a defined set of quality control criteria that are accepted across clinical disciplines and international boundaries, the pace of discovery and proofs of efficacy and safety will accelerate for adipose tissue-derived cell products. Additionally, it will be important to refine and standardize assays and methods used to quantify adipose tissue-derived cells in a reproducible manner. In addition to developing shared standard operating procedures for each assay, it may be useful to establish international reference laboratories for individual tests. These outcomes are likely to benefit all constituencies, 

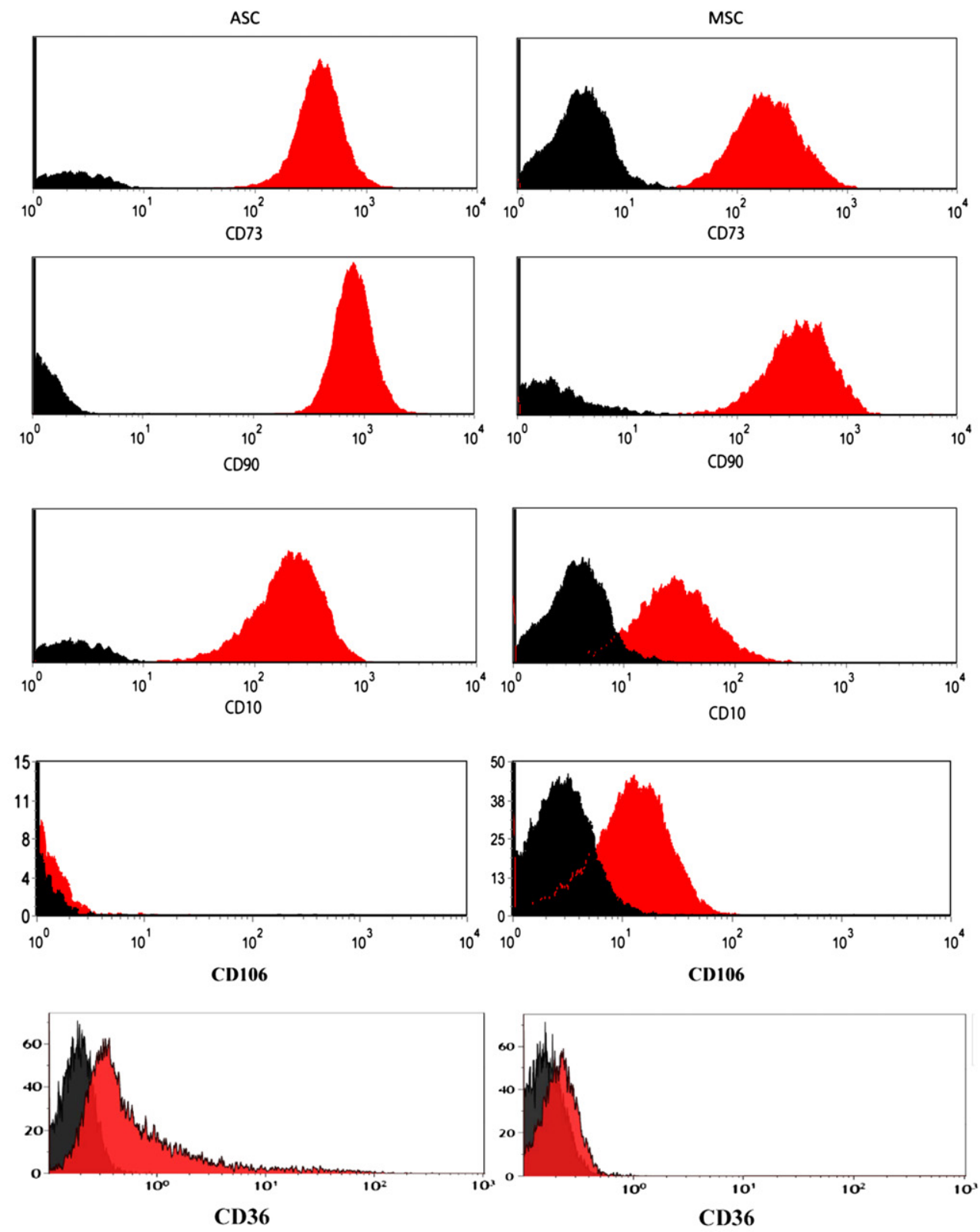

Figure 2. A phenotypic comparison of cultured ASCs (left column) and MSCs (right column) showing similarities (CD73, CD90) and differences (CD10, CD36 and CD106) between the two types of stromal cells. The plots came from several laboratories of the authors.

including patients, physicians, surgeons and biotechnologists, who share a stake in the promising field of adipose tissue cell therapeutics.

Disclosure of interest: Although the purpose of this statement paper is to advance the field in an impartial manner, the authors recognize that a range of activities may be perceived as having potential for a conflict of interest. To ensure transparency, the authors acknowledge the following relationships: $\mathrm{PB}$ is a consultant for Celgene and collaborates with ABCell
Bio. BAB has pending patents. LC collaborates with CSA21, founded CSA21 and has four international patents. MD founded Rigenerand srl and has pending patents. AJK is a consultant for BioTime, Inc., MicroAire, Inc. and LifeCell, Inc., founded The GID Group and Stemsource, Inc. (now Cytori Therapeutics) and has multiple issued and pending U.S. and foreign patents. KLM is a consultant for Tissue Genesis Inc. and American Medical Sciences, collaborates with Advanced Technologies \& Regenerative Medicine and Biomet, founded $\mathrm{S}$ and $\mathrm{K}$ Discoveries and has U.S. PTO-2 issued and six 
applications. HR is a consultant for Baxter Innov., Bio and Bio, Evercyte and AMI and founded Trauma Care Consult. JPR is a consultant for Cohera Medical and advisor to GID group. KY collaborates with Kaneka, Inc. JMG is a consultant for Advanced Technologies \& Regenerative Medicine, Anterogen, Mentor, Stemmatters and Toucan Capital, collaborates with Cognate Bioservices, Medpace/Mesoblast, Vesta Therapeutics and Zen-Bio, founded Artecel Sciences and LaCell and has multiple issued and pending U.S. and foreign patents.

\section{References}

1. Dominici M, Le Blanc K, Mueller I, Slaper-Cortenbach I, Marini F, Krause D, et al. Minimal criteria for defining multipotent mesenchymal stromal cells. The International Society for Cellular Therapy position statement. Cytotherapy. 2006;8:315-7.

2. Zuk PA, Zhu M, Ashjian P, De Ugarte DA, Huang JI, Mizuno H, et al. Human adipose tissue is a source of multipotent stem cells. Mol Biol Cell. 2002;13:4279-95.

3. Hollenberg $\mathrm{CH}$, Vost A. Regulation of DNA synthesis in fat cells and stromal elements from rat adipose tissue. J Clin Invest. 1969;47:2485-98.

4. Friedenstein AJ, Piatetzky S II, Petrakova KV. Osteogenesis in transplants of bone marrow cells. J Embryol Exp Morphol. 1966;16:381-90.

5. Gimble J, Guilak F. Adipose-derived adult stem cells: isolation, characterization, and differentiation potential. Cytotherapy. 2003;5:362-9.

6. Gimble JM, Katz AJ, Bunnell BA. Adipose-derived stem cells for regenerative medicine. Circ Res. 2007;100:1249-60.

7. Cawthorn WP, Scheller EL, MacDougald OA. Adipose tissue stem cells meet preadipocyte commitment: going back to the future. J Lipid Res. 2012;53:227-46.

8. McIntosh K, Zvonic S, Garrett S, Mitchell JB, Floyd ZE, Hammill $\mathrm{L}$, et al. The immunogenicity of human adipose derived cells: temporal changes in vitro. Stem Cells. 2006;24:1245-53.

9. Mitchell JB, McIntosh K, Zvonic S, Garrett S, Floyd ZE, Kloster A, et al. Immunophenotype of human adipose derived cells: temporal changes in stromal- and stem cell-associated markers. Stem Cells. 2006;24:376-85.

10. Cousin B, Andre M, Arnaud E, Penicaud L, Casteilla L. Reconstitution of lethally irradiated mice by cells isolated from adipose tissue. Biochem Biophys Res Commun. 2003; 301:1016-22.

11. Han J, Koh YJ, Moon HR, Ryoo HG, Cho CH, Kim I, et al. Adipose tissue is an extramedullary reservoir for functional hematopoietic stem and progenitor cells. Blood. 2010;115: 957-64.

12. Zuk PA, Zhu M, Mizuno H, Huang J, Futrell JW, Katz AJ, et al. Multilineage cells from human adipose tissue: implications for cell-based therapies. Tissue Eng. 2001;7:211-28.

13. Erickson GR, Gimble JM, Franklin DM, Rice HE, Awad H, Guilak F. Chondrogenic potential of adipose tissue-derived stromal cells in vitro and in vivo. Biochem Biophys Res Commun. 2002;290:763-9.

14. Gronthos S, Franklin DM, Leddy HA, Robey PG, Storms RW, Gimble JM. Surface protein characterization of human adipose tissue-derived stromal cells. J Cell Physiol. 2001;189:54-63.

15. Planat-Benard V, Silvestre JS, Cousin B, Andre M, Nibbelink $M$, Tamarat $R$, et al. Plasticity of human adipose lineage cells toward endothelial cells: physiological and therapeutic perspectives. Circulation. 2004;109:656-63.

16. Li H, Zimmerlin L, Marra KG, Donnenberg VS, Donnenberg AD, Rubin JP. Adipogenic potential of adipose stem cell subpopulations. Plastic Recon Surgery. 2011;128: 663-72.

17. Choi YS, Vincent LG, Lee AR, Dobke MK, Engler AJ. Mechanical derivation of functional myotubes from adiposederived stem cells. Biomaterials. 2012;33:2482-91.

18. Im GI, Shin YW, Lee KB. Do adipose tissue-derived mesenchymal stem cells have the same osteogenic and chondrogenic potential as bone marrow-derived cells? Osteoarthritis Cartilage. 2005;13:845-53.

19. Huang JI, Kazmi N, Durbhakula MM, Hering TM, Yoo JU, Johnstone B. Chondrogenic potential of progenitor cells derived from human bone marrow and adipose tissue: a patientmatched comparison. J Orthop Res. 2005;23:1383-9.

20. Gimble JM, Bunnell BA, Chiu ES, Guilak F. Concise review: adipose-derived stromal vascular fraction cells and stem cells: let's not get lost in translation. Stem Cells. 2011;29:749-54.

21. Gimble JM, Guilak F, Bunnell BA. Clinical and preclinical translation of cell-based therapies using adipose tissue-derived cells. Stem Cell Res Ther. 2010;1:19.

22. Casteilla L, Planat-Benard V, Laharrague P, Cousin B. Adipose-derived stromal cells: their identity and uses in clinical trials, an update. World J Stem Cells. 2011;3:25-33.

23. Zimmerlin L, Donnenberg V, Pfeifer M, Peault B, Rubin JP, Donnenberg A. Stromal vascular progenitors in adult human adipose tissue. Cytometry. 2010;77(Part A):22-30.

24. Pachon-Pena G, Yu G, Tucker A, Wu X, Vendrell J, Bunnell BA, et al. Stromal stem cells from adipose tissue and bone marrow of age-matched female donors display distinct immunophenotypic profiles. J Cell Physiol. 2011;226: 843-51.

25. Sengenes C, Lolmede K, Zakaroff-Girard A, Busse R, Bouloumie A. Preadipocytes in the human subcutaneous adipose tissue display distinct features from the adult mesenchymal and hematopoietic stem cells. J Cell Physiol. 2005;205:114-22.

26. Maumus M, Peyrafitte JA, D’Angelo R, Fournier-Wirth C, Bouloumie A, Casteilla L, et al. Native human adipose stromal cells: localization, morphology and phenotype. Int J Obes (Lond). 2011;35:1141-53.

27. Lanza F, Healy L, Sutherland DR. Structural and functional features of the CD34 antigen: an update. J Biol Regul Homeost Agents. 2001;15:1-13.

28. Castro-Malaspina H, Gay RE, Resnick G, Kapoor N, Meyers P, Chiarieri D, et al. Characterization of human bone marrow fibroblast colony-forming cells (CFU-F) and their progeny. Blood. 1980;56:289-301.

29. Astori G, Vignati F, Bardelli S, Tubio M, Gola M, Albertini V, et al. "In vitro" and multicolor phenotypic characterization of cell subpopulations identified in fresh human adipose tissue stromal vascular fraction and in the derived mesenchymal stem cells. J Transl Med. 2007;5:55.

30. Katz AJ, Tholpady A, Tholpady SS, Shang H, Ogle RC. Cell surface and transcriptional characterization of human adiposederived adherent stromal (hADAS) cells. Stem Cells. 2005; 23:412-23.

31. Yu G, Wu X, Dietrich MA, Polk P, Scott LK, Ptitsyn AA, Gimble JM. Yield and characterization of subcutaneous human adipose-derived stem cells by flow cytometric and adipogenic mRNA analyzes. Cytotherapy. 2010;12:538-46.

32. Seda Tigli R, Ghosh S, Laha MM, Shevde NK, Daheron L, Gimble J, et al. Comparative chondrogenesis of human cell sources in 3D scaffolds. J Tissue Eng Regen Med. 2009;3: 348-60. 